\title{
Towards more equitable terms of cooperation: local people's contribution to commercial timber concessions
}

\author{
A. RAVIKUMAR ${ }^{1}$, K. ANDERSSON ${ }^{1}$, E. MWANGI ${ }^{2}$, M.R. GUARIGUATA² and R. NASI ${ }^{2}$ \\ ${ }^{1}$ University of Colorado at Boulder, 397 UCBB, Boulder, CO 80309-0397, USA \\ ${ }^{2}$ Centre for International Forestry Research (CIFOR), Bogor, Indonesia
}

Email: ashwin.ravikumar@colorado,edu,krister.andersson@colorado.edu, e.mwangi@cgiar.org,m.guariguata@cgiar.org, and r.nasi@cgiar.org

\begin{abstract}
SUMMARY
The mixed outcomes of seemingly well-intentioned partnerships that try to create mutually beneficial agreements between local communities and private firms remain a puzzle. This study looks for answers to this puzzle by reviewing a large number of empirical studies in a wide variety of contexts. The kinds of local skills and expertise that are important for good timber concession management, how local people and concession managers can construct mutually profitable relationships, the most effective strategies used by communities to defend their claims in conflicts with private firms, and the types of public policies that are supportive of more equitable terms of cooperation in forest concession management are issues that were examined in the review. Institutional arrangements that regulate the relationship between local communities and forest concessionaires, and particularly the distribution of de jure property rights, help explain the mixed results. Less conclusive evidence exists with regards to community perspectives on concession-community relationships. The study concludes by suggesting future directions for research and discusses the implications of the findings for public policy.
\end{abstract}

Keywords: timber concessions, partnerships, benefit-sharing, cooperation, local governance

\section{Cheminement vers des termes plus équitables de coopération: la contribution des populations locales aux concessions de bois de coupe commerciales}

\author{
A. RAVIKUMAR, K. ANDERSON, E. MWANGI, M. GUARIGUATA et R. NASI
}

Les résultats mitigés de partenariats bien intentionés visant à créer des accords mutuellement bénéfiques entre les communautés locales et les firmes privées demeurent une énigme. Cette étude cherche des réponses en examinant un grand nombre d'études empiriques dans une grande variété de contextes. Les genres de talents et de connaissances locaux importants pour une bonne gestion de concessions de bois de coupe, la façon dont les populations locales et les gestionnaires des concessions peuvent établir des relations mutuellement profitables, les stratégies les plus efficaces dont se servent les communautés pour défendre leurs droits dans des conflits avec les firmes privées et les types de politiques publiques soutenant des termes plus équitables de coopération dans la gestion des concessions forestières sont des questions étudiées dans l'article. Les arrangements institutionnels contrôlant la relation entre les communautés locales et les concessionnaires forestiers, particulièrement la distribution de droits de propriété "de jure", expliquent les résultats mixtes. Des preuves moins conclusives existent dans les perspectives des communautés sur les relations concessions-communautés. L'étude conclut avec des suggestions pour des directions futures de recherche et examine les implications des résultats pour les politiques publiques.

\section{En busca de términos de cooperación más equitativos: Contribución de las comunidades locales a las concesiones madereras comerciales}

\author{
A. RAVIKUMAR, K. ANDERSSON, E. MWANGI, M. GUARIGUATA y R. NASI
}

Aun sigue siendo un misterio la existencia de resultados contradictorios de los consorcios entre comunidades locales y empresas privadas, en principio bien intencionados, para la creación de acuerdos mutuamente beneficiosos. Este estudio busca respuestas a este interrogante mediante la revisión bibliográfica de un elevado número de estudios empíricos desarrollados en una amplia variedad de contextos. Entre los temas examinados en esta revisión están el tipo de habilidades y experiencia local necesarias para gestionar bien una concesión maderera, oportunidades para la creación de relaciones mutuamente beneficiosas entre las comunidades locales y los gestores de concesiones, las estrategias más efectivas empleadas por las comunidades para defender sus reivindicaciones en los conflictos con empresas privadas, y los tipos de políticas publicas en apoyo de una cooperación más equitativa en la gestión de concesiones forestales. Las disposiciones institucionales que regulan las relaciones entre comunidades locales y titulares de concesiones forestales, y en particular la distribución de los derechos de propiedad de iure, ayudan a explicar estos resultados contradictorios. Son menos, sin embargo, las pruebas concluyentes existentes con respecto a los puntos de vista de las comunidades sobre sus relaciones con las empresas concesionarias. Este estudio concluye ofreciendo sugerencias de posibles líneas de investigación futuras y discute las repercusiones de los resultados en cuanto a políticas públicas. 


\section{INTRODUCTION}

Despite a recent increase in scholarship on relationships between local forest users and timber concession holders, there is still limited understanding of why there are such mixed outcomes of seemingly well-intentioned partnerships between these groups. Why are some efforts successful in creating mutually beneficial agreements while others are not? What are some of the contextual and structural factors that help explain such variation in outcomes? This study looks for answers to these questions. A large number of empirical studies from a wide variety of national and local contexts were reviewed. Particular attention was given to the following dimensions: local skills and expertise important for timber concession management; ways in which local people and concession managers can construct mutually profitable relationships; effective strategies used by communities to defend their claims when in conflict with private firms; and the types of public policies that are supportive of more equitable terms of cooperation in forest concession management. These dimensions were selected to inform CIFORs research program on the sustainable management of production forests. ${ }^{1}$

By investigating existing interactions between communities and companies - including how arrangements can be mutually beneficial or not and how conflicts can be more or less amenably resolved - the framework is laid for further investigations of these problems. An improved understanding of community-company interactions in timber concessions may inform better policies for helping communities to assert their rights, and provide insights into the conditions that favour desirable outcomes in forest social ecological systems.

The main finding of this review is that the institutional contexts at national as well as local levels help explain why some community-company relationships are mutually beneficial while many others benefit only the holders of the concessions. ${ }^{2}$ Existing studies converge on one common result: when commercial forest concessions are left to operate without effective institutional constraints, local user groups are more vulnerable and often end up losing out from the establishment of concessions. Most studies also agree that when concessions are effectively constrained, communities tend to lose less or, in some cases, even gain a net benefit.

Three main knowledge gaps were identified by the review. First, there is a lack of empirically grounded analysis of the interactions between communities and timber concession holders. Besides the World Bank (2009) and Nawir et al. (2003), which collected original data from experts involved in concession-community partnerships and concession holders, East Kalimantan there has been very little systematic field data collection for comparative analysis on this topic. Other studies have collected field data to address issues related to forest concessions and social aspects in general, but not specifically focusing on interactions between timber concession holders and local communities (i.e. see Mendoza and Prabhu 2000, Palmer 2004, Donovan and Puri 2004, Becker and Ghimire 2003, Thapa et al. 1995, among others). Further studies also focus on interactions between timber companies and local communities, without an explicit focus on concessionary arrangements (e.g., Mayers and Vermeulen 2002).

Second, there is a lack of community perspective on concession-community relationships. For example, the study by the World Bank (2009) fails to capture the community perspective. Out of the 89 actors that were interviewed for that study, only one was a community representative. It is difficult to assess what is working and what is not when it comes to community-company relationships when the analysis considers only one side of the relationship. While studies such as Nawir et al. (2003) and Menton et al. (2009) engage with local forest users in the data-collection for their studies, our review finds that most researchers who study communitycompany relationships do not interact directly with forest users to capture their perspective. As a result, the views and preferences of community members and what opportunities they see for making concession arrangements work more in their favour, remains largely understudied in the broader literature.

Finally, the review was unsuccessful in identifying a single existing study that explicitly compares cases with contrasting tenure regimes. Yet it appears that the national property rights regime and associated statutory rights, and especially the degree to which local communities enjoy primacy over the allocation of forest management rights on the lands where they live, has a major effect on the likelihood of concessions yielding more equitable outcomes for local groups.

The paper is organized as follows: The first section discusses the review's methodology. The second section focuses on local skills and expertise important for timber concession management. The third section considers how local communities and concession management can interact in mutually beneficial ways. The fourth section reflects on how policies and strategies for concession management might be improved, and the fifth section identifies knowledge gaps that merit further research.

\section{REVIEW APPROACH}

Studies to be included in the review were selected according to three search criteria. Those selected met at least two of these: (1) have high relevance for timber concession management OR to community forest management more generally,

See http://www.cifor.org/fileadmin/templatesnew/res/documents/CIFOR_s_strategy_2008-2018/CIFORStrategy0802.pdf.

2 The focus of this paper is on current concession management systems, however colonial legacies (or lack thereof) may influence the current acceptability of the concession model and the management/negotiation arrangements adopted (see Singer and Karsenty, 2008; Hardin, 2002). 
(2) present original data AND/OR conduct original analysis of existing data, OR (3) be identified by CIFOR as potentially relevant.

Searches were conducted in the ISI Web of Knowledge, ScienceDirect, Springerlink, and Google scholar. Search terms included "community forest management", "forest concessions community impacts", "timber concessions community impacts", "community company forest conflict", and "decentralized community forest management", as well as combinations of these terms. These search terms produced a total of 928 hits, with variable relevance for the review. 200 studies that seemed the most relevant were selected based on their titles. All 200 abstracts were read and 46 studies were identified that fit the selection criteria, and these were included in this systematic review. An additional 24 studies were included at the suggestion of CIFOR and affiliated researchers who reviewed early drafts of this paper. Most studies reviewed were in English and limited to peer-reviewed articles in the selected databases.

The 70 studies included in the review represent a diversity of methodologies. Cross-sectional surveys and questionnaires, case studies employing focus groups and workshops, and broad comparative case studies are all well represented. Many meta-analyses and studies that assess available data from government and other sources are referenced as well. In addition, several ethnographies, remote sensing studies, and mixed method studies are included. Figure 1 presents the methodologies of these studies.

\section{Systematic review methods}

The review of the selected studies began with the identification of the main research findings as they pertain to the questions of interest for this review. Based on the result of that first

\section{FIGURE 1 Methodologies of cited studies}

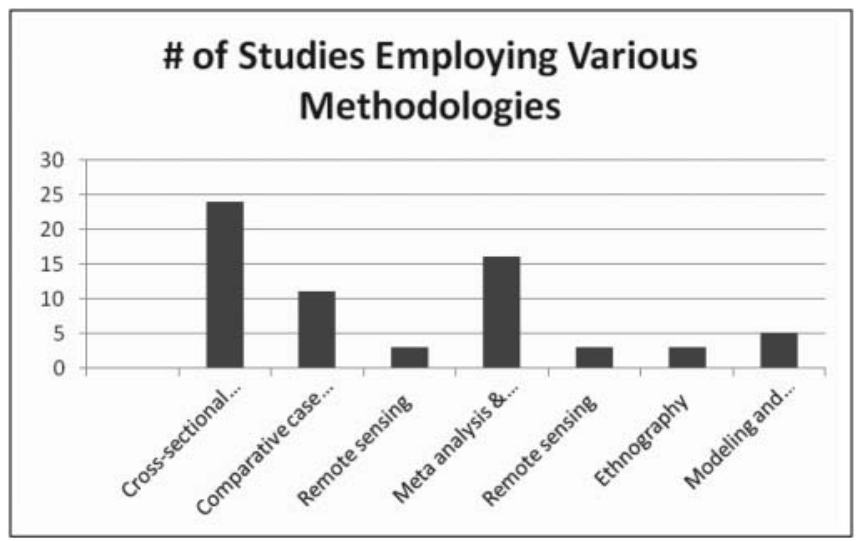

step, possible knowledge gaps relevant to each question were also identified. In addition to assessing the content and substantive findings of each document, the associated methodological approaches of the research were also examined. For this component of the review the guidelines for systematic reviews published by the Centre for Evidence-Based Conservation, $2010^{3}$ were followed. Two main types of criteria for assessing the research methods were applied: (1) reliability, precision and uncertainty, and (2) validity.

Reliability refers to the extent to which the methods employed producing consistent results. Precision refers to the narrowness of the error margin due to sampling error, and the uncertainty criterion refers to the degree of explicit recognition to the various sources of uncertainty in the study. Finally, validity is the degree to which the concept of interest is appropriately measured. The assessment focused on the internal validity of studies. External validity assessments require access to details of the research methodology applied-information that was unavailable for many of the studies in the review. These two types of criteria allowed an assessment of the extent to which the reviewed studies and their findings were limited by different methodological biases, such as selection bias, performance bias, measurement or detection bias, and attrition bias ${ }^{4}$ (Centre for Evidence-Based Conservation, 2010). Table 1 (see Appendix) presents the key datadriven studies that were included in the review as well as our qualitative assessment of these studies according to the main criteria.

The rest of this report addresses central research questions: (1) what kinds of local skills and expertise are important for timber concession management? (2) How can local people and concession managers interact in mutually profitable ways? (3) In the event of community-concession conflicts, how do communities organize to defend their claims? and (4) How might policies and strategies for concession management be improved? A separate section identifies knowledge gaps. Each section contains a discussion of how the reviewed literature addresses the questions of interest.

\section{LOCAL SKILLS AND EXPERTISE IMPORTANT FOR TIMBER CONCESSION MANAGEMENT}

The documents reviewed present a long list of potential contributions of local knowledge to the management of timber concessions. By providing essential local information related to "time and place", local people can improve the quality and cost-effectiveness of planning and implementation of any activity in which external actors are involved, including timber concession activities (Ostrom et al. 1993, Gibson

\footnotetext{
3 Guidelines available at http://www.environmentalevidence.org/documents/guidelines.pdf

4 Drawing on the guidelines for systematic reviews developed by the Centre for Evidence-Based Conservation (2010), we refer to selection bias as the systematic errors associated with choosing sources of data, causing the sample to be biased relative to the population. Performance bias is error introduced as a result of the study itself, e.g., a timber company changing its behavior because it is under study. Measurement (detection) bias is error introduced by the particular measure of a concept that is employed. Attrition bias refers to error introduced when certain data points drop out of a study for systematic reasons.
} 
et al. 2005). The integration of local and western scientific knowledge can facilitate the economic, ecological, and social sustainability of a timber concession. As laid out by Kainer et al. (2009), local ecological knowledge usefully complements western science by, for example, highlighting relevant extremes in ecological variability where western scientists would emphasize average trends. In Amazonia, the combination of local ecological knowledge and western management science proved essential to creating an efficient vertically integrated timber industry (Sears et al. 2007). Antionori and Bray (2005) found similar benefits to the co-utilization of western management science of local knowledge in timber production in Mexico. Local ecological knowledge can help concessionaires identify appropriate management practices for specific areas of the concession area in question (e.g. Thapa et al. 1995, Carney 2003) and help identify alternative species with the same desirable physical properties as the species currently harvested commercially (Turner et al. 2000). Such local knowledge of species has been useful in other timber concession contexts. Lacerda and Nimmo (2010) find that one of the problems of forest management planning in the Brazilian Amazon is that commercial concessionaires' forest inventories are inaccurate. If concessionaires hire local community members as para-taxonomists, the authors show that the accuracy of forest inventories may be improved. Another essential contribution of local knowledge, which appears to be largely underutilized in these relationships, is the knowledge of the local social context. Examples of this type of knowledge is how social networks operate--the who's who in local decision making about forestry--and what forest management strategies are likely to work in this local context.

There are few discussions of partnerships between timber concession holders and local communities that highlight the value of local ecological knowledge and other expertise. There has been some discussion of its utility in the technical forest management literature, however, and there is also research that suggests that traditional ecological knowledge is particularly valuable in managing non-timber forest products. In Indonesia, with decentralization of government and associated changes in forest policies as well as in the established intergovernmental relationships, came the need for further specification of property rights in concession lands (Barr 2001).

Given the diversity of flora in management areas, local expertise has proven to be valuable because communities have unique knowledge of relevant species (Berkes 2000, Carney 2003). Where non-timber forest products have economic value, traditional ecological knowledge can be particularly important. Turner et al. (2000) find that indigenous tribes in British Columbia are highly knowledgeable about the interactions between different components of the ecosystem, with knowledge of many local species. In Nepal, agroforestry is dependent on fodder trees to feed livestock (Thapa et al. 1995). The productivity of these trees is crucial for many peoples' livelihoods, so sustainable management of the shared resources is important to local stakeholders. Tree-crop interactions like splash erosion depended on leaf size and texture, crown density, and tree size; farmers had extensive knowledge of over 90 trees, and the types of interactions they might have with different crops. In Indonesia, non-timber forest products such as the gaharu resin, produced from Aquilaria trees and used in cosmetic products, have been managed effectively with involvement from local communities with specialized knowledge (Donovan and Puri 2004). In Northern Bolivia, the extraction of Brazil nut (Bertholletiaexcelsa) is made principally by local communities on concession and other lands (Guariguata et al. 2009). Thousands of rural families' livelihoods depend on the management of this non-timber forest product (Cronkleton and Pacheco, 2008). Since 2003, the monetary value of Brazil nut exports from Bolivia has actually exceeded that of timber (CamaraForestal of Bolivia, 2007).

There is also evidence that communities can implement strategies for preservation, when communication between other stakeholders is effective. In Ecuador, discussions between NGOs and Western experts concerning the potential impact of deforestation on local water quality led communities to reshape their own forest management strategies, with the effect of increasing preservation (Becker and Ghimire 2003).

Figure 2, below, summarizes the overlapping roles that local user communities can play in improving concession management. The studies reviewed suggest three main categories of skills and expertise that communities may bring to the table. Ecological knowledge refers to understanding of local climate and tree species, as well as non-timber forest products that can be developed as value added products in concession lands. Social knowledge includes the capacity to organize, information about how local networks and decision making operate, and confer a social license to operate to companies. Working knowledge refers to the ability to contribute useful labour, based on usable local knowledge of time and place (Hayek 1945). This may be valuable knowledge about the forest that only individuals who have lived in the location for a very long time will have. Examples include which parts of the forest are inaccessible by foot, how to get from one location to another as quickly and safely as possible, where treacherous swamps are, where to find potable water, etc. Having local employees with this type of knowledge can be invaluable for a timber firm. The sizes of the bubbles in the diagram correspond to the proportion of studies that refer to these types of community contributions.

\section{INTERACTIONS BETWEEN LOCAL COMMUNITIES AND CONCESSION MANAGERS}

There are several ways in which concession holders may cooperate with local communities. Nebel et al. (2003) describe the challenges faced by communities in commercial forestry, and propose partnerships with companies as a possible strategy for handling problems such as the lack of technical expertise and market access. Nepstead et al. (2003) argue that forestry should be encouraged in areas where communities are present, in order to take advantage of mutually 
FIGURE 2 Possible community contributions to timber concession management

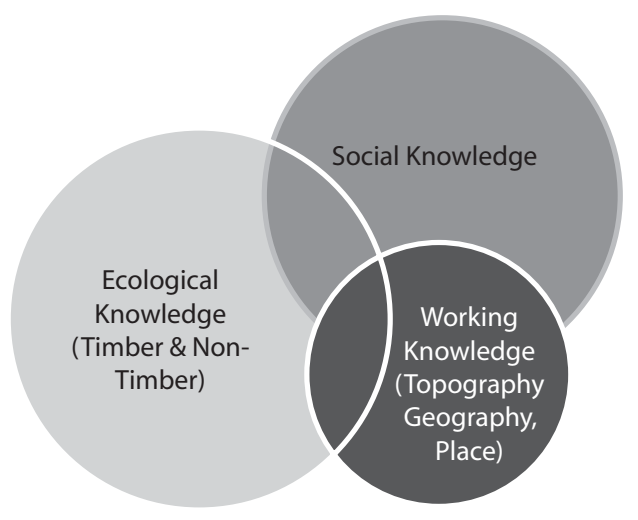

beneficial opportunities. This review identified three main types of cooperative agreements, as detailed below. In all of the arrangements described, two recurring challenges to developing mutually beneficial agreements are (1) identifying areas of common interest between parties, and (2) measuring success. Lynam et al. (2007) propose a set of tools that may be used for generating information that can help overcome these challenges and may hence form the basis for forging more equitable partnerships.

\section{Benefit-sharing agreements}

These agreements provide opportunities for profit-sharing to members of local communities. These are typically worked out so that a certain share of annual profits from the timber concession is paid to community representatives. Other variations of such agreements, such as paying a fixed amount at specified intervals or a one-time payment, also exist. Another type of benefit sharing agreement provides a particular contribution, either monetary or in kind, to the benefit of the project, regardless of the performance of the timber concession (World Bank 2009, Mayers and Vermeulen 2002). Such contributions may involve a specified number of jobs, or the building of a community centre, schools, health clinics, etc. (Nawir et al. 2003). Most studies point out that profit-sharing agreements that make periodic payments over time cultivate better relationships as they provide stronger incentives for cooperation on both sides of the bargain (e.g. see Palmer, 2004). Benefit sharing has been documented in many geographical contexts. It has been noted in Indonesia (Nawir et al. 2003, Barr 2001), in East and Central Africa (Perez et al. 2005, Marfo et al. 2010), and in Latin America (Mayers and Vermeulen 2002). Problems associated with benefitsharing agreements have been noted. For example, in the Amazon, Medina et al. (2006) have found that benefit sharing arrangements, which are by far the most common partnerships that occur in their region of study, led to very small benefits per household. Unequal distributions of benefits within communities have also been observed (Tokede et al. 2005, Sommerville 2010). In the latter cases, elites often capture a disproportionate share of benefits, or compensation payments do not go to community members who then end up losing the most from the arrangement. Both of these serve as examples of inadequately constrained interactions yielding inequitable outcomes. The existing studies often refer to the prevalence of elite capture occurring, but few studies explain why it occurs and under which conditions it might be mitigated. It is argued that this is one of the major knowledge gaps to be addressed by future research.

Tax loopholes and poor governance may lead companies to not pay as much as they might have to if the communities' rights were clearer (Samsu 2004). Benefit-sharing schemes are useful mechanisms for compensating communities for the loss of land uses that compete with timber production. Moreover, benefit-sharing can be implemented through a variety of mechanisms, with the potential to be modified to fit particular situations.

\section{Management sharing or co-production agreements}

These are contracts that assign specific forest management responsibilities to community members and specify the corresponding compensation for performing such actions. Like benefit-sharing, management sharing is a broad category of possible arrangements between concession holders and communities. Nawir et al. (2003) describe tree-growers in Indonesia as actively managing timber resources along with forest concession holders. In this situation, tree-growers sell their products to concession holders at agreed upon prices. The case studies described by Nawir et al. in fact represent both benefit-sharing as well as management sharing, indicating that these types of cooperative arrangements are not mutually exclusive.

In general, there is a great range of other strategies for management sharing. In West Java, the government supports community participation in virtually all aspects of forest governance. They manage systems for agroforestry, monitor illegal logging and theft, inspect wood production facilities, and agree to act in the interest of forest conservation (Mayers and Vermeulen 2002). Elsewhere, communities participate by managing only certain aspects of forest governance, such as hunting (Vermeulen et al. 2009), with impacts for biodiversity, which has been found to suffer from logging if not properly managed (Van Vlietand Nasi 2008, Meijaard et al. 2006). In contrast to both of these systems, Canadian forests are often managed entirely by indigenous communities who have formed companies of their own (Mayers and Vermeulen 2002). Ros-Tonen et al. (2008) studied a variety of companycommunity partnerships in the Brazilian Amazon, distinguishing between politically-oriented, product-oriented, and multi-sector partnerships. They find evidence that show that communities can benefit from management sharing activities, such as community production of NTFPs like Brazil nut oil and acai fruit, provided that institutional arrangements are cost-effective, and gross benefits are sufficient for all stakeholders. 


\section{Forest management out-grower schemes}

Concession holders can also establish out-grower schemes, which are contractual agreements that ask local community members to sell their products harvested from their individual or community land to the concession holders for an agreed upon price (Vidal 2004). Out-grower schemes have been used in a wide variety of contexts, at times in conjunction with other management sharing and benefit sharing arrangements (but see FAO, 2001). Out-grower schemes are commonly used in South Africa (Mayers and Veremeulen 2002). In these arrangements, companies provide community members with market connectivity and production capabilities to participate in the production of timber directly. Community members may then plant trees or manage their existing natural forest, and manage either type of forest with the intention of selling at least part of the harvest to the firm that has organized the outgrowing scheme. Such an arrangement goes beyond a simple benefit-sharing one, in that community members do not just accept compensation for land use or timber that is produced by the company, but has more control over the management and harvesting processes (Vidal 2004). Companies benefit from these arrangements, as with others, by gaining access to land and raw materials that wouldn't otherwise have been accessible. Community members have benefited from the income provided by timber sales, and have gained additional benefits, for example from intercropping trees with legumes. Although access to markets is a necessary condition for communities to participate in commercial tree growing, it may not be sufficient for doing so profitably. Without access to credit, for example, communities may not have enough capital to make the necessary investments required for costeffective production(Pokorny 2008, Sikor 2004, World Bank 2009).

There are a number of plausible benefits that communities and companies could accrue through these partnership arrangements. Mayers and Vermeulen (2002) summarize many of these benefits from the perspective of companies. These benefits include building social capital to increasing the stability of operations, enhancing the company's national and international image in the interest of future operations, and gaining eligibility for forest certification programs necessary for participation in international markets (Nawir et al. 2003).

Communities can also benefit by gaining opportunities for employment and sometimes by sharing income from timber in the area (World Bank 2009). Other benefits include greater potential returns to inputs, diversification of production by permitting non timber forest products to be developed, increases in the security of land rights, and upgrades to infrastructure (Mayers and Vermeulen 2002). Roads, infrastructure, and social services offered by companies can serve as strong incentives for communities to join partnerships (Nawir et al. 2003). Effectively enforced contracts to ensure that these incentives are upheld are critical for such arrangements.

Nevertheless, the degree to which these benefits can be recognized depends on a variety of conditions. Contracts that are clear and enforceable can be effective tools for placing all partners on a common footing; moreover, recent research has highlighted mutual respect, trust, practicality and communication as critical components of a mutually beneficial partnership (World Bank 2009). The benefits to communities are enhanced if company practices do not conflict with local beliefs, if taxation structures are permissive of payments for environmental services, and if communities have secure property rights (Purnomo et al. 2003). Other research suggests that institutional factors, such as corruption levels, property rights security, and pre-existing wealth endowments can affect the outcomes of community natural resource management. Keller et al. (2000) find that the equitability, sustainability and efficiency outcomes of community natural resource management are highly variable. They find that community forest management has a higher success rate in places like North America, but much less successful in Kenya and Nepal, suggesting that having a single resource at issue (such as one timber species), strong legal support for community management, and well developed organizational infrastructure all contribute to this disparity in outcomes. Figure 3, shows the relationship between these mutually profitable arrangements, emphasizing that there are often overlaps between these mechanisms; they are not necessarily mutually exclusive, although few experiences exist in which these are combined in the field.

\section{COMMUNITY ORGANIZATION IN RESPONSE TO COMMUNITY-CONCESSION CONFLICTS}

There are many contexts in which companies harvest timber from concession lands, and accordingly there are several types of conflicts that can arise. Literature that comprehensively discusses conflicts between timber companies and communities is relative sparse. There is even less information on the types of conflicts that can occur specifically in timber concession lands. From the extant literature, we identify four types of conflicts between local communities and commercial

FIGURE 3 Mutually beneficial arrangements between timber companies and communities

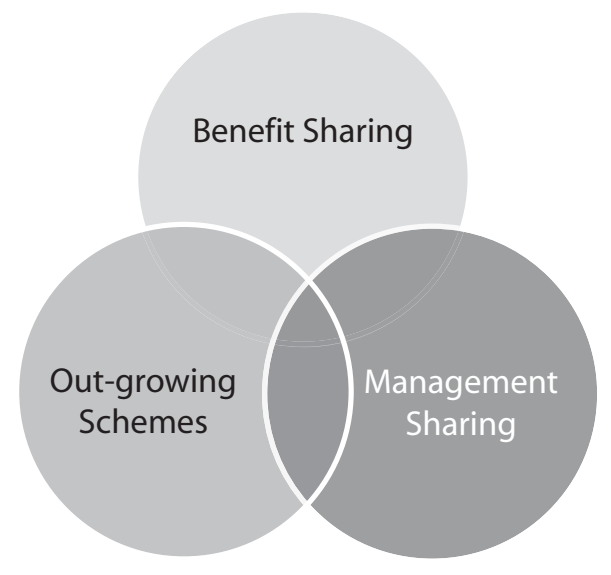


timber concessions. The first type occurs when historical customary community rights are not recognized by either timber concessions or the national government. In this worstcase scenario, rural communities have few options to protect their claims, and may have no other choice than to resort to obstruction or even sabotage against the concession, as exemplified by the cases in Indonesia (Barr 2001, Palmer 2004). A second type of conflict is when a national government law formally recognizes historical customary forest user rights, but enforcement of this law is weak, and may be inconsistent with concession allocation policies. For example, in postSuharto Indonesia, timber concession lands frequently overlapped with community-claimed land giving rise to land disputes, (Barr 2001). A third type of conflicts are associated with situations in which communities' land rights are vaguely recognized so that communities negotiate with the timber concessionaires, but communities are frustrated by the lack of feasible mechanisms for ensuring a fair negotiation process (Palmer 2004). Finally, when agreements are made, a fourth type of conflict may emerge if communities and companies lack effective mechanisms for enforcing the agreed benefit sharing - making sure that each party live up to their end of the bargain (Barr 2001, Palmer 2004).

When conflicts do emerge between communities and companies, there are several conceivable mechanisms for resolution. In the worst cases, there have been instances of violent clashes and protests where communities have come into conflict with timber companies (Palmer 2004, Barr 2001). In spite of this, partnerships have the potential to provide peaceful mechanisms for conflict resolution, depending on institutional arrangements including the strength of property rights ,the degree of decentralization in government, the type of resource at issue, and the structure of the community (Purnomo et al. 2003, Palmer 2004). Where partnerships do exist, there are more specific mechanisms by which communities can organize themselves to defend their claims. Direct bargaining, litigation, and negotiation through local government are all possible strategies. Other intermediates, such as farmer collectives, can also serve as intermediates for bargaining and negotiation (Nawir et al. 2003). Studies have consistently shown that the relative bargaining power, and strength of local governments, can influence which of these approaches is most likely to be used successfully. For example, Purnomo et al. (2003) explicitly model these outcomes based on the degree of control that communities and companies have at the outset, and find that bargaining and litigation occur depending on institutional conditions such as the strength of property rights and the reliability of courts. Other factors also influence the type of conflict resolution mechanism that is employed including the strength of communities' propensity for collective action (Palmer 2004).

The extent to which community members engage collectively in forest management activities depends in part on the institutional context. For example, in the Amazon frontier of Brazil, Merry et al. (2006) find that community-based associations constitute important centres for collective action, which enable communities to benefit from concession partnerships-more specifically, they find that in places with strong association partnerships with timber companies tend to increase local people's active involvement in these organizations. Another institutional factor that seems to matter for the outcome of the partnership is the involvement of a third party. Engel et al. (2006), in a game theoretical exploration, describe the plausible effects of NGOs in improving communities' bargaining power. They find that while NGOs may be able to intervene in conflicts to empower communities to assert their rights, there may be environmental costs associated with this process, including a net increase in forest degradation. This occurs, the authors argue, because as community bargaining power increases (through NGO intervention, for example), the timber company must share a greater proportion of its net benefits. Since the rent-per-area of the forest is likely to increase through this process, this may produce incentives to increase logging (i.e. see Mertens et al. 2001). To compensate for this loss, the company may try to increase overall logging, and the community would have little incentive to fight this. While this is an intriguing possibility, the authors do not validate their formal model's predictions with field data. The role of NGOs as potential facilitators of effective benefit sharing processes remains debated. For example, Marfo et al. (2009) analyse conflict outcomes with and without mediation by third parties such as NGOs, and find that NGO mediation may empower community actors as well.

The existing institutional conditions in communities seem to predispose different conflict resolution mechanisms. Community leadership - both formal and informal -has been shown to be an important channel in settling boundary disputes in many cases (Nawir et al. 2003). The strength of local government may also help communities to defend their rights, as may the presence and activities of NGOs. On the other hand, insecure property rights and land designations - such as overlapping and chaotic classification systems - and lack of institutional stability can allow companies to profit from concession lands without due compensation to communities (Kartodihardjo 2000). Ndoye et al. (2003) suggest that there is an a priori approach to conflict resolution. They advocate for community-based forest management systems, in which communities are given further forest property rights. They argue that this can not only avert conflict before it materializes, but also provide communities with de jure ammunition in their struggle to assert themselves against often powerful interests.

Figure 4, below, outlines the types of mechanisms available to communities in asserting their rights in cases of conflict. The options that are available depend to a large extent on the property rights regimes that are in place. For example, if communities have de jure land rights and primacy to management rights, government agencies and courts may be used effectively to assert their claims. In the absence of de jure access, on the other hand, these mechanisms may not be available and mediation by third parties, collective action, or even civil disobedience may emerge as viable avenues for bargaining. 
FIGURE 4 Community mechanisms for asserting rights in cases of conflict

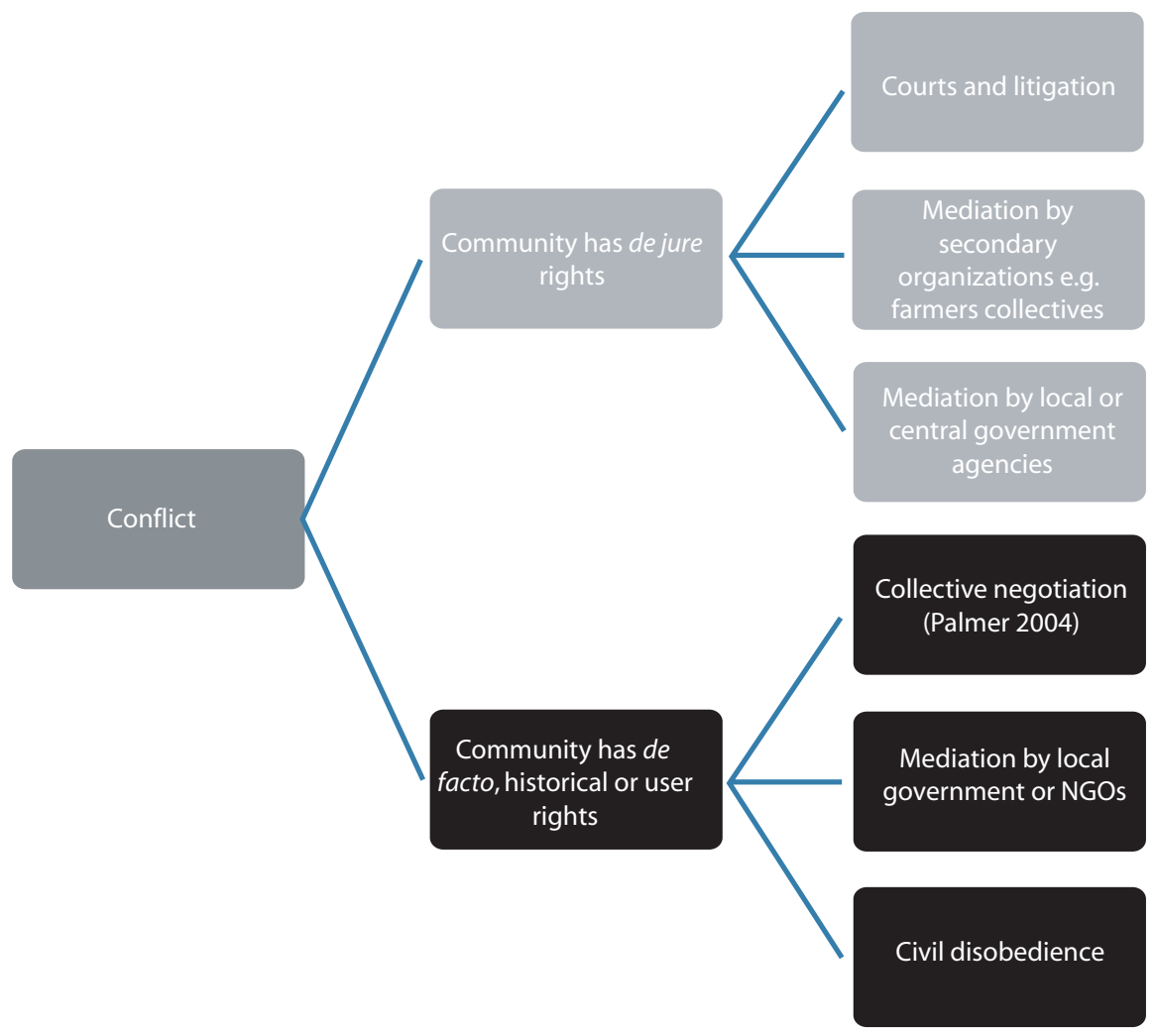

\section{IMPROVING POLICIES AND STRATEGIES FOR CONCESSION MANAGEMENT}

Mutually beneficial partnerships between local forest user groups and timber concession holders are not likely to materialize without public policies that actively promote such agreements. Government's promotion of more equitable benefit sharing in this context needs to go beyond rhetoric and creating regulatory standards for concession-community partnerships (although both these types of support may indeed help) and address some of the fundamental reasons why local forest user groups often find themselves in a disadvantaged position from which it is difficult to negotiate. There are several policy interventions that can help accomplish a strengthened bargaining position of local communities. Based on existing policy reform experiences in a variety of national contexts, we discuss three types of interventions: (1) Property rights reform; (2) Decentralization policies; (3) Centralized regulations and standards.

\section{Property Rights Reform}

The most important reason why local forest user groups often find themselves in such disadvantaged positions when they interact with commercial timber concessions is their lack of clear and secure property rights. (Larson et al. 2010). In the absence of clear property rights, communities can be exploited, and conflicts are more likely. In the case of Fiji, Murti and Boydell (2008) find that conflicts are based primarily on confusion over property rights, and that these conflicts have severe adverse environmental and social consequences.

Perhaps the most important role of governments at all levels is to reduce uncertainties with regards to the specification, allocation, and enforcement of these property rights for any given forest. When local people do not have de jure rights that correspond to their de facto rights, and outsiders do not perceive the local rights as clear, concession holders have been known to extract and profit from resources without paying communities who are the de facto managers of the land (Kartodihardjo 2000, Kellert et al. 2000). When rights are clear but weak for the local community and their use of forests, there is some evidence to suggest that local government or NGO interventions may increase the bargaining power of communities (Engel et al. 2006, Andersson 2004, 2010).

In Indonesia, it appears that local user groups involved in joint concession management with longer time horizons, such as the HPH concession arrangement, perceive less uncertainty and stronger tenure security which results in stronger incentives for long-term investments in resource improvements (Iskandar et al. (2009). There is also some evidence that just recognizing communities' right to apply for forest management permits can strengthen the local groups' ability to exclude outsiders who have laid claims on their resource, even if the local groups do not apply for such permits (Kusters et al. 2007).

In some countries, governments are slow to give local communities a full bundle of de jure property rights (Larson 
et al. 2010, Ribot 2002). Even in those situations, however, there may still be ways in which government policies can help reduce uncertainties associated with tenure when concession rights are assigned. Short of recognizing local user's de jure rights to forests, governments could make it a point to take into account the boundaries of de facto user rights prior to delimiting the concession areas so as to reduce the risk for boundary disputes between concessions and local forest users. Another factor that affects outcomes in concessions is their size, and this should be considered in allocating concession rights (Karsenty et al. 2008). Another possible policy option is to allocate community concession lands, which are distinct from concessions operated by private firms. These have been attempted in Petén, Guatemala, as well as throughout Bolivia via through so-called Asociaciones Sociales del Lugar (ASLs).

Bray et al. (2008) studied the environmental and social impacts of community concessions in Guatemala using available data and remote sensing, aiming to compare these community concessions to "strictly protected areas." They found no significant difference in deforestation between community concession lands and "strictly protected areas," but assert that a "web of evidence" apart from their study point to community concessions having better environmental outcomes (see also: Ellis and Porter-Bolland (2008)). They also found that communities gain a greater economic benefit in community concessions than they would in strictly protected areas. Nittler and Tschinken (2005) studied the Guatemalan context as well. Their findings, based on available data, suggest that community concessions provide more environmental and social benefits, such as conservation and income respectively, than competing land uses such as national parks and "multiuse zones." They find that there are two important needs for success in community concessions. First, communities must cooperate. Communities are often heterogeneous (with many languages in a small area), and this can impede cooperation. Where communities have cooperated to form forestry based businesses, they have generated income and benefitted. Second, there must be strong governance and excellent outside support for communities in developing their industries. Ezzinede Blas et al. (2011) find that where conflict is persistent, poor governance can be perpetuated and further conflict can be created, as has been found in Cameroon. They argue further that poor governance of benefit sharing schemes and lack of transparency in transactions are likely to generate more conflict. In this sense, poor governance at the local level can be self-perpetuating, and central governments may thus be instrumental in strategies to improve local governance conditions, for example in backstopping the enforcement of benefit sharing rules.

de Jong et al. (2006) studied the ASL (Asociaciones Sociales del Lugar) concessions in Bolivia, to determine how successful they are. They conclude that wherever there is an economically valuable resource, local and outside elites will attempt to control it. Thus, community forest management in community concessions is vulnerable to takeover, and must be protected by strict governance. Pacheco (2005) discussed these requirements further, again in the Bolivian context. His research suggests that community concession systems (ASLs) in Bolivia did not succeed as much as they might have because of excessive bureaucracy. To participate, communities had to meet many requirements, including proving residence in an area and showing that a certain number of people were part of their group, many were unable to meet these requirements. Many ASLs did not even have their requests processed by the government, and the result was illegal logging. The benefits of these arrangements are still unclear, and questions remain for further research.

Finally, even if the current tenure transition continuesthrough which community-owned forest areas increase at the expense of government ownership of the resource-and rural communities gain ever clearer and more secure property rights, this is only the first step towards more equitable benefit-sharing. In order to improve the inherently disadvantaged positions of forest dwelling communities, especially in terms of the lack of opportunities for developing human capital, more equitable terms of cooperation between local communities and commercial concession holders should be pursued. Active involvement by some local governments in Indonesia illustrate how local communities' negotiation position may be strengthened when a governmental authorities steps in on their side of the table (Obidzinski and Barr 2001, Palmer 2004) Playing the role of "passive regulators" may not be enough to give local communities equal standing in negotiations with timber firms.

\section{Decentralization Policies}

When national governments decide to decentralize their governance arrangements for forests-by transferring specific rights, responsibilities and resources from the centre down to more local levels - these decisions often alter the balance of power within the forestry sector (Ribot 2002, Larson et al. 2008). In the new configuration of policy actors that emerge in the aftermath of decentralization reforms, local governments constitute a more important actor. For local communities, who are trying to assert their rights and legitimacy as forest users, the new policy landscape offers opportunities to create new strategic alliances with the decentralized government authorities.

Local communities may strengthen their positions vis-àvis commercial timber concessions if the local governments, empowered by the decentralization reforms, support the communities' claims. The likelihood of this occurring, however, will depend on several contextual factors, such as the extent to which local governments are downwardly accountable to local forest user groups (Agrawal and Ribot, 1999, Andersson et al. 2006) and upwardly accountable to a government authority that expects the decentralized regime to support local resource communities (Andersson 2003). The downward accountability of local governments, in turn, is facilitated by competitive, democratic local elections as well as the level and strength of organizations that represent local forest user group interests (Gibson and Lehoucq 2003, Cerutti et al. 2010) while upward accountability depends on the top-down efforts to monitor local performance (Andersson 2006). 
This means that in places where the local government actors and their interests are more closely aligned with the timber concessions, decentralization may actually hurt the local community claims. The direction of the effects of decentralization reforms on local community positions boils down to local politics and how this translates into accountability mechanisms. More specifically, the extent to which local communities will be able to persuade local government authorities to side with them rather than the timber concessionaires depends to a large extent on the relative political capital that these actors represent for local politicians.

While there is little theoretical support for the a priori expectation that decentralization will always help the cause of local user groups, the empirical studies that have looked at this relationship have found a predominantly positive effect of decentralization on local user group positions (Obidzinski and Barr 2001, Carney et al. 2005). There is also evidence that local governments can serve as mediators of community interests in conflicts. In these cases, it appears that local politicians have perceived the political incentives to accommodate demands from the electorate represented by local user groups to be stronger than the financial incentives associated with pleasing the timber industry (Marfo et al. 2010). These findings do not necessarily represent a general trend, however, and one should be careful about inferring an observed positive effect of decentralization on equitable outcomes in concession-community relationships. More systematic investigations that rely on a more representative sample of local jurisdictions are needed to substantiate such patterns.

One of the issues that reformers in this area need to contend with is the possible conflict between local and central government definitions of property rights regimes (Yasmi et al. 2005). If decentralization succeeds in bringing government closer to the people, more local resource user groups who were previously excluded from the political process are now able to assert and defend their de facto property rights regimes through engaging the local government authority. This may be perceived as a threat to the established de jure property rights regime and all of the powerful actors who benefit from the status quo. If these powerful actors are threatened, the conflict is likely to be messy, long and highly disruptive for all forest users because it will increase uncertainty. Yasmi et al. (2005) suggest that decentralization has proceeded in a non-uniform fashion, with variable outcomes. In particular, though decentralization will in theory improve accountability to communities by bringing the government closer to them, local governments run a risk of having insufficient funds to carry deliver necessary services (McCarthy 2001). There are cases in which, for example they find that communities have ostensible autonomy over forest governance, while in reality a relatively small group of elites and businessmen make most important decisions.

We suggest that there are two possible ways to mitigate this problem. First, powers could be devolved to the point that the local government is entirely responsible for assigning and demarcating timber concessions. This seems like a highly unlikely outcome since central governments would lose control over one of the most important sources of income in the forestry sector. Second, and a more plausible solution, is that central governments maintain the right to assign timber concessions, but are required to secure the approval of local governments to ensure that there are no problematic conflicts between de facto and de jure property rights on the ground.

\section{Centralized Regulations and Standards}

To move towards more equitable terms of cooperation between timber firms and local user communities, we recognize that there are essential roles to be played by policy actors at various levels. Some governance responsibilities are best handled by local governments while others are not. For example, it may not make much sense to allow local governments to create whatever regulations for assigning timber concessions within their jurisdiction as doing so would eliminate the possibility for up-ward accountability. The interventions that would most strengthen the position of local user groups are therefore a combination of (a) centralized regulations and standards concerning the formation of community-concession partnerships and (b) decentralized mandates to support and oversee such partnerships on the ground.

Another role for centralized standards and regulations is to promote certification frameworks. When certification programs are desirable, the communities' bargaining positions are improved, as companies aim to meet standards (Nawir et al. 2003). Certification can incentivize the protection of local rights, and ensure that conflict resolution mechanisms are in place in concessions. Empirically, company actors involved in partnerships have been satisfied with activities aimed at certification as well (World Bank 2009).

In Indonesia, there have been two types of concessions. IPPK concessions (no longer in use at the time of this writing) are short term community concessions that expire after just a few years. HPH concessions are longer term commercial concessions. Both are required to meet certain standards, particularly with respect to clear property rights (Kellert et al. 2000). Moreover, there are certain standards that companies must adhere to in extracting timber and dealing with communities, particularly in HPH concessions (Iskandar et al. 2009). Thus, communities may be in a better position to assert property rights when the central government has standard practices. Environmental outcomes can also be improved if sustainable practices are required and monitored effectively (Boscolo et al. 2009). Scherr et al. (2004) argue that the central government should provide technical assistance to communities to enhance their capacity for forest management.

Another role for centralized regulations concerns the introduction of potential countermeasures to local elite capture. Even in cases where communities have been able to reach beneficial agreements with timber concessionaires, these benefits may not flow to the community as a whole but rather to a select, few elite members. There is empirical evidence that elite capture is an issue. Tokede et al. (2005) found elite capture to be a significant constraint to one of the basic goals for forging partnerships between communities 
and concessionaires: to enhance community development. Their study found that while partnerships often produced increased direct involvement of local people in forest management and provided much needed short-term benefits for local communities, they also found that "the benefits from timber revenues have not been fairly shared among local people and other actors involved in the timber business. As a result, community forestry cooperatives have yet to contribute to equitable and sustainable development for local people." Sommerville et al. (2010) find that programs that promote payments for ecosystem services can result in a net benefit for communities. Nevertheless, while there are overall net benefits, community members that suffer the greatest opportunity costs from, for example, agriculture, are not adequately compensated for their losses. This underscores the importance of looking at communities as heterogeneous groups with competing interests and needs internally.

The problem is potentially prevalent in forest user communities, but again, few systematic studies exist to determine how common elite capture actually is in community-based natural resource management (Andersson and Laerhoven 2007, Plateau 2004). To ensure more equitable outcomes from partnerships at the community level, centralized standards that emphasize principles of fairness and social justice in local decision making bodies, may have a role to play. One way that standards for equitable arrangements can be operationalised is laid out by Laplante and Spears (2008). The authors argue that socially responsible companies must obtain free, prior, and informed consent from communities before operating, through clearly defined and inclusive processes that are mediated by disinterested third parties (see reference to Marfo, 2009 in earlier sections of this paper which show that NGOs were successful conflict mediators). Central governments may take the additional step of requiring proof of such consent before issuing logging permits. The biggest challenge is not to create these standards, however, but to monitor and enforce them on the ground.

\section{IDENTIFICATION OF KNOWLEDGE GAPS}

Among the studies that have been examined, Mayers and Vermeulen (2002) provide the most comprehensive treatment of the different types of beneficial partnerships, with their associated challenges, that can be developed between communities and timber companies. After analyzing cases of community-company interaction from around the world, the authors summarize the conditions under which companies and communities may win or lose, noting that they differ depending on whether or not deals are in place. Under circumstances where raw materials are inaccessible, or there is a high risk of resistance from communities, companies are likely to lose out without a deal, on the other hand, companies can do fine without making a deal if there is little pressure from communities, or it is easy to just buy land through local elites. Conversely to these situations, companies are likely to lose out with deals if the transaction costs are high and the processes are very complicated, but they can benefit from deals if those arrangements help to secure raw materials, labour, or the 'social license to operate' from a community, consumers, or investors.

Communities are likely to lose out in the absence of deals if there are few opportunities for livelihoods in the region, or if it is not feasible to develop land/trees without companies, but they can benefit from deals if their self-determination is unaffected by company agendas, and livelihoods are not skewed by single strategies (that may lead to increased vulnerability). The converse situations for communities are that they may lose out with deals, if they become locked into dependencies or cheated by companies, or pressured into sub-optimal uses of land. With deals they may win by gaining additional income in the absence of other opportunities, or by increasing their capacity for development projects.

The circumstances that predispose desirable or undesirable outcomes for the company thus seem comparatively simple. The perspective of the community is somewhat murkier, however, and several questions remain. What determines the cost of negotiating for the community? What makes them more or less likely to negotiate successfully? What power structures within communities are best suited for such negotiations? To what degree do community institutions operate to produce outcomes, independently of socioeconomic conditions (to what extent do community institutions matter?) Further studies with field data would be instructive in answering these questions.

Another area that has not been studied is how benefits are distributed within communities. Given that communities are underrepresented in the literature in general, it seems particularly important to understand the dynamics of benefit sharing within communities, and how these dynamics differ among different communities. We expect that elites capture benefits to some degree, but what circumstances serve to exacerbate or mitigate this effect? And more: in what ways might benefit sharing arrangements within communities influence their capabilities and incentives for collective action? Studies of the institutional conditions that predispose elite capture of benefits would be extremely useful in understanding the true impact of community-company partnerships. Partnerships that appear to transfer benefits to, or share responsibilities with communities, may not actually do as much good as they appear if community members do not share benefits equitably. In addition, the gendered impacts of communitycompany partnerships are understudied, but there is evidence that timber production in general may produce gender inequities. Veuthey and Gerber (2009) find that women may not receive benefits at all from timber production, and may bear greater social, cultural, and economic costs from the industry. What might community-company partnerships do to these gender dynamics?

A third area of future study is the role of property rights structures in making concessions successful. What rights are there to the resource, and how are these rights enforced? For example, does government allocate extraction rights to communities when they are given rights to land? Or are 
extraction rights separate from user rights? A comparative study that examines the different types of property rights that are assigned by governments in concession lands would be extremely instructive to policy makers. There is evidence in the literature that secure land tenure predisposes better management of land, but it is not known exactly what types of property rights are best suited for forest concessions. One possible direction for research in this area is to compare how contrasting de jure rights interact with varying de facto governance arrangements, such as self-made rules about access and use, self-organized monitoring and enforcement, as well as local sanctioning systems.

\section{CONCLUSION}

This review was framed around five questions that were purposely formulated to inform CIFORs research on the sustainable management of production forests. A systematic review of research was undertaken following guidelines drawn by the Centre for Evidence-Based Conservation. Several studies have looked at the relationship between communities and concession managers, but important knowledge gaps still remain. This article has identified several of these gaps: First, studies specific to interactions between concession managers and communities are few in numbers. Moreover, most of those that we found were focused on Indonesia only, with many regions understudied. While this may be an artifact of the review methodology, with databases that mostly captured peer-reviewed articles in English, the field could benefit from more comparative analyses. Second, where studies have comprehensively examined these relationships, there are often biases. A study by Nawir et al. (2003) is one of the more complete studies of how communities have been impacted by interactions with concession holders. Other studies of local people's interaction with timber firms often suffer from under-sampling indigenous and local communities, relying heavily on expert opinion instead (World Bank 2009). The true nature of these interactions therefore remains uncertain, and further studies that address these questions while including the perspective of community members irrespective of the willingness of associated concession managers to participate in research - are necessary for further development of our collective understanding of the factors that shape the performance of community-company relationships.

Governance is a thread that runs through all the sections and findings of this review-with institutional arrangements, enforcement of contracts and property rights, and conflict mediation-as principal concerns. This is not surprising as the effectiveness of interactions that involve a sharing and distribution of benefits are predicated on how these interactions are negotiated and implemented. Such negotiation and implementation extends beyond the relevant communities and companies, to include NGOs, as well as local and central governments; it is thus a multi-actor domain that cuts across multiple levels of governance.

\section{ACKNOWLEDGEMENTS}

This research was carried out as part of the CGIAR Research Programme, 'Forests, Trees and Agroforestry: Livelihoods, Landscapes and Governance'. The Programme aims to enhance management and use of forests, agroforestry and tree genetic resources across the landscape from forests to farms. The Center for International Forestry Research leads the collaborative Programme in partnership with Bioversity International, the International Center for Tropical Agriculture and the World Agroforestry Centre. The authors would like to thank Paolo Cerutti, Andrew Wardell, Cesar Sabogal, Moira Moeliono, Alain Karsenty along with three anonymous reviewers for their constructive comments and suggestions on earlier drafts.

\section{REFERENCES}

AGRAWAL, A. and RIBOT, J. 1999. Accountability in decentralization: a framework with south Asian and African cases. Journal of Developing Areas 33(4): 473-502.

ANDERSSON, K. 2003. "What motivates municipal governments? Uncovering the institutional incentives for municipal governance of forest resources in Bolivia." Journal of Environment and Development 12(1): 5-27.

ANDERSSON, K. 2004. Who talks with whom? The role of repeated interactions in decentralized forest governance. World Development 32(2): 233-249.

ANDERSSON, K. 2006. Understanding decentralized forest governance. Sustainability: Science, Practice, \& Policy 2(1): 25-35.

ANDERSSON, K. 2010. Whose support matters most: The role of external actors in community governance of forests in Bolivia. Working Paper

ANDERSSON, K. GIBSON, C. and LEHOUCQ, F. 2006. Municipal politics and forest governance. World Development 34(3): 576-595.

ANDERSSON, K. and VAN LAERHOVEN, F. 2007. From local strongman to facilitator: Institutional incentives for participatory municipal governance. Comparative Political Studies 40(9): 1085-1111.

ANTINORI, C. and BRAY, D. B. 2005. Community forest enterprises as entrepreneurial firms: economic and institutional perspectives from Mexico. World Development 33(9): 1529-1543.

BARR, C.M. 2001. The impacts of decentralisation on forests and forest-dependent communities in Malinau district, East Kalimantan: CIFOR Case studies on decentralisation and forests in Indonesia. Case Study 3.

BARR, C. M. 2001. Banking on sustainability: structural adjustment and forestry reform in Post-Suharto Indonesia. CIFOR Macroeconomics for sustainable development office.

BECKER, C., \& GHIMIRE, K. 2003. Synergy between traditional ecological knowledge and conservation science supports forest preservation in Ecuador. Conservation Ecology 8(1): 1. 
BERKES, F., COLDING, J., and FOLKE, C. 2000. Rediscovery of traditional ecological knowledge as adaptive management. Ecological Applications 10(5): 1251-1262.

BOSCOLO, M., SNOOK, L., and QUEVEDO, L. 2009. Adoption of sustainable forest management practices in Bolivian timber concessions: a quantitative assessment. International Forestry Review 11(4): 514-523.

BRAY, D. B., E. DURAN, V. H. RAMOS, J.-F. MAS, A. VELAZQUEZ, R. B. MCNAB, D. BARRY, and RADACHOWSKY, J. 2008. Tropical deforestation, community forests, and protected areas in the Maya Forest. Ecology and Society 13(2): 56.

CARNEY, D. 1995 Management and supply in agriculture and natural resources: is decentralisation the answer? ODI Natural Resource Perspectives 4, June.

CERUTTI, P. 2006. Forests, illegality, and livelihoods in Cameroon. CIFOR Working Paper 35.

COLAN, V., CATPO, J., POKORNY, B., \& SABOGAL, C. 2007. Costos del aprovechamiento forestal para seis empresas concesionarias en la región Ucayali, Amazonía Peruana. In: SABOGAL, C. and SOBREVILLA, V. (eds.) Monitoreo de operaciones de manejo forestal en concesiones con fines maderables de la Amazonía peruana. Pucallpa, Peru: CIFOR and INRENA.

DE BLAS, D. E., RUIZ-PÉREZ, M., \&VERMEULEN, C. 2011. Management conflicts in Cameroonian community forests. Ecology and Society 16(1): 8.

DE JONG, W., RUIZ, S., \& BECKER, M. 2006. Conflicts and communal forest management in northern Bolivia. Forest Policy and Economics 8(4): 447-457.

DONOVAN, D. and PURI, R. 2004. Learning from traditional knowledge of non-timber forest products: Penan Benalui and the autecology of Aquilaria in Indonesian Borneo. Ecology and Society 9(3): 3.

DOUGLAS, J. and SIMULA, M. 2010. The future of the world's forests: ideas vs. ideologies: Springer: World forests Vol VIII.

ELLIS, E. and PORTER-BOLLAND, L. 2008. Is community-based forest management more effective than protected areas?: A comparison of land use/land cover change in two neighbouring study areas of the Central Yucatan Peninsula, Mexico. Forest Ecology and Management 256(11): 1971-1983.

ENGEL, S., LOPEZ, R., and PALMER, C. 2006. Community-industry contracting over natural resource use in a context of weak property rights: the case of Indonesia. Environmental and Resource Economics 33(1): 73-93.

GALARZA, E., \& LA SERNA, K. 2005. Las concesiones forestales en el Perú: ¿cómo hacerlas sostenibles? In $L a$ política forestal en la Amazonía y Los Andes. Estudios de caso, Bolivia, Ecuador y Perú. Consorcio de Investigación Económica y Social (CIES).

GIBSON, C. and F. LEHOUCQ. 2003. The local politics of decentralized environmental policy. Journal of Environment and Development 12(1): 28-49

HAYEK, F.A. 1945. The use of knowledge in society. 1945. American Economic Review 35(4): 519-530.
ISKANDAR, H., SNOOK, L. K., TOMA, T., MACDICKEN, K. G., and KANNINEN, M. 2009. A comparison of damage due to logging under different forms of resource access in East Kalimantan, Indonesia The decentralization of forest governance: politics, economics and the fight for control of forest in Indonesian Borneo. Earthscan, London, UK.

KAINER, K. A., DIGIANO, M. L., DUCHELlE, A. E., WADT, L. H. O., BRUNA, E., and DAIN, J. L. 2009. Partnering for greater success: local stakeholders and research in tropical biology and conservation. Biotropica, 41(5): 555-562.

KARSENTY, A., DRIGO, I., PIKETTY, M., \& SINGER, B. 2008. Regulating industrial forest concessions in central Africa and South America. Forest Ecology and Management 256(7): 1498-1508.

KARTODIHARDJO, H., and SUPRIONO, A. 2000. The impact of sectoral development on natural forest conversion and degradation: The case of timber and tree crop plantations in Indonesia. CIFOR Occasional Paper \#26E.

KELLERT, S., MEHTA, J., EBBIN, S., and LICHTENFELD, L. 2000. Community natural resource management: promise, rhetoric, and reality. Society \& Natural Resources 13(8): 705-715.

KUSTERS, K., DE FORESTA, H., EKADINATA, A., and VAN NOORDWIJK, M. 2007. Towards solutions for state vs. local community conflicts over forestland: The impact of formal recognition of user rights in Krui, Sumatra, Indonesia. Human Ecology 35(4): 427-438.

LACERDA, A. E. B. D., \&NIMMO, E. R. 2010. Can we really manage tropical forests without knowing the species within? Getting back to the basics of forest management through taxonomy. Forest Ecology and Management 259(5): 995-1002.

LAPLANTE, L., \& SPEARS, S. 2008. Out of the Conflict Zone: The Case for Community Consent Processes in the Extractive Sector. Yale Hum. Rts. \& Dev. LJ 11: 69-78.

LARSON, A. M. CRONKLETON, P. BARRY, D. PACHECO, P. 2008. Tenure Rights and Beyond: Community Access to Forest Resources in Latin America. CIFOR Occasional Paper No. 50.

LARSON, A.M. BARRY, D. DAHAL, G.R.ANDCOLFER C.J.P. (eds.) 2010. Forests for people: Community rights and forest tenure reform. Earthscan, London, UK.

LYNAM, T., DE JONG, W., SHEIL, D., KUSUMANTO, T., and EVANS, K. 2007. A review of tools for incorporating community knowledge, preferences, and values into decision making in natural resources management. Ecology and Society 12(1): 5.

MARFO, E., and SCHANZ, H. 2009. Managing logging compensation payment conflicts in Ghana: Understanding actor-empowerment and implications for policy intervention. Land Use Policy 26(3): 619-629.

MAYERS, J., \&VERMEULEN, S. 2002. Companycommunity forestry partnerships: From raw deals to mutual gains. Instruments for sustainable private sector forestry series. International Institute for Environment and Development: London, UK. 
MCCARTHY, J. 2001. Decentralisation and forest management in Kapuas district, Central Kalimantan. CIFOR Case studies on decentralisation and forests in Indonesia. Case Study 2.

MEIJAARD, E., SHEIL, D., NASI, R., and STANLEY, S. E. 2006. Wildlife conservation in Bornean timber concessions. Ecology and Society 11(1): 47.

MEDINA, G., POKORNY, B., and CAMPBELL, B. 2009. Community forest management for timber extraction in the Amazon frontier. International Forestry Review 11(3): 408-420.

MENDOZA, G. A., \&PRABHU, R. 2000. Multiple criteria decision making approaches to assessing forest sustainability using criteria and indicators: a case study. Forest Ecology and Management 131(1-3): 107-126.

MENTON, M., MERRY, F. D., LAWRENCE, A., \& BROWN, N. 2009. Company-community logging contracts in Amazonian settlements: impacts on livelihoods and NTFP harvests. Ecology and Society 14(1): 39.

MERRY, F., AMACHER, G., POKORNY, B., LIMA, E., SCHOLZ, I., NEPSTAD, D., \&ZWEEDE, C. 2003. Some doubts about concessions in Brazil: should Brazil shelve its proposed system of forest concessions? ITTO Tropical Forest Update 13: 3.

MERTENS, B., FORNI, E., \&LAMBIN, E. 2001. Prediction of the impact of logging activities on forest cover: A case-study in the East province of Cameroon. Journal of Environmental Management 62(1): 21-36.

MURTI, R., \&BOYDELL, S. 2008. Land, conflict and community forestry in Fiji. Management of Environmental Quality: An International Journal 19(1): 6-19.

NAWIR, A., SANTOSO, L., \&MUDHOFAR, I. 2003. Towards mutually-beneficial company-community partnerships in timber plantation: lessons learnt from Indonesia. CIFOR, Bogor, Indonesia. 55 p.

NDOYE, O., \&TIEGUHONG, J. 2004. Forest resources and rural livelihoods: the conflict between timber and nontimber forest products in the Congo Basin. Scandinavian Journal of Forest Research 19: 36-44.

NEBEL, G., JACOBSEN, J. B., QUEVEDO, R., and HELLES, F. 2003. A strategic view of commercially based community forestry in indigenous territories in the lowlands of Bolivia. CIFOR Rural Livelihoods, Forests, and Biodiversity Conference Paper.

NEPSTAD, D., AZEVEDO-RAMOS, C., \& LIMA, E. 2005. Governing the Amazon timber industry for maximum social and environmental benefits. Forests, Trees and Livelihoods 15: 183-192.

NITTLER, J., \&TSCHINKEL, H. 2005. Community forest management in the Maya Biosphere Reserve of Guatemala: protection through profits. USAID Steering Committee on Nature, Wealth and Power.

OBIDZINSKI, K., \& BARR, C. M. 2003. The effects of decentralization on forests and forest industries in Berau District, East Kalimantan. CIFOR Case studies on decentralisation and forests in Indonesia. Case Study 2.
PACHECO, P. 2005. Decentralization of forest management in Bolivia. Earthscan, London, UK.

PACHECO, P., DE JONG, W., and JOHNSON, J. 2010.The evolution of the timber sector in lowland Bolivia: Examining the influence of three disparate policy approaches. Forest Policy and Economics 12(4): 271-276.

PALMER, C. (2004). The role of collective action in determining the benefits from IPPK logging concessions: a case study from Sekatak: East Kalimantan. CIFOR Working Paper.

PLATTEAU, J. 2004. Monitoring elite capture in communitydriven development. Development and Change 35(2): 223-246.

POKORNY, B., \& JOHNSON, J. 2008. Community forestry in the Amazon: The unsolved challenge of forests and the poor. ODI Natural Resource Perspectives 112(4).

PURNOMO, H., MENDOZA, G., \& PRABHU, R. 2004. Model for collaborative planning of community-managed resources based on qualitative soft systems approach. Journal of Tropical Forest Science 16(1): 106-131.

PURNOMO, H., MENDOZA, G., PRABHU, R., and YASMI, Y. 2005. Developing multi-stakeholder forest management scenarios: a multi-agent system simulation approach applied in Indonesia. Forest Policy and Economics 7(4): 475-491.

RIBOT, J. 2002. Democratic Decentralization of Natural Resources: Institutionalizing Popular Participation. Washington, DC: World Resources Institute.

ROS-TONEN, M. A. F., VAN ANDEL, T., MORSELLO, C., OTSUKI, K., ROSENDO, S., \&SCHOLZ, I. 2008. Forest-related partnerships in Brazilian Amazonia: There is more to sustainable forest management than reduced impact logging. Forest Ecology and Management 256(7): 1482-1497.

RUIZ PÉREZ, M., EZZINE DE BLAS, D., NASI, R., SAYER, J., SASSEN, M., ANGOUÉ, C., and GAMI, N. 2005. Logging in the Congo Basin: A multi-country characterization of timber companies. Forest Ecology and Management 214(1-3): 221-236.

SABOGAL, C., DE JONG, W., POKORNY, B., and LOUMAN, B. Manejo forestal comunitario en América Latina: experiencias, lecciones aprendidas y retos para el futuro. CIFOR, Bogor, Indonesia, $274 \mathrm{p}$.

SAMSU, K. 2004. Small scale 100 ha logging concessions' contribution to regional finance: case study in Bulungan district. CIFOR Decentralisation Brief.

SCHERR, S., WHITE, A., and KAIMOWITZ, D. 2004. Making markets work for forest communities. In ZARIN D. (ed.) Working forests in the neotropics: Conservation through sustainable management 130-155.

SEARS, R., PADOCH, C., and PINEDO-VASQUEZ, M. 2007. Amazon Forestry Transformed: Integrating Knowledge for Smallholder Timber Management in Eastern Brazil. Human Ecology 35(6): 697-707.

SIKOR, T. 2010. Conflicting concepts: contested land relations in north-western Vietnam. Conservation and Society 2(1): 75 . 
SOMMERVILLE, M., JONES, J. P. G., RAHAJAHARISON, M., \& MILNER-GULLAND, E. J. 2010. The role of fairness and benefit distribution in community-based Payment for Environmental Services interventions: A case study from Menabe, Madagascar. Ecological Economics 69(6): 1262-1271.

STEFANIEENGEL, R. L., PALMER, C. 2006. CommunityIndustry Contracting over Natural Resource Use in a Context of Weak Property Rights: The Case of Indonesia. Environmental \& Resource Economics 33: 73-93.

THAPA, B., SINCLAIR, F., and WALKER, D. 1995. Incorporation of indigenous knowledge and perspectives in agroforestry development. Agroforestry Systems 30(1): 249-261.

TOKEDE, M. J., WILIAM, D., WIDODO, GANDHI, Y., IMBURI, C., PATRIAHADI, MARWA, J., and YUFUAI, M. C. 2005. The impact of special autonomy on Papua's forestry sector: empowering customary communities (masyarakatadat) in decentralized forestry development in Manokwari district. CIFOR, Bogor, Indonesia.

TURNER, N., IGNACE, M., and IGNACE, R. 2000. Traditional ecological knowledge and wisdom of aboriginal peoples in British Columbia. Ecological Applications 10(5): 1275-1287.
VAN VLIET, N., and NASI, R. 2008. Mammal distribution in a Central African logging concession area. Biodiversity and Conservation 17(5): 1241-1249.

VERMEULEN, C., JULVE, C., DOUCET, J., and MONTICELLI, D. 2009. Community hunting in logging concessions: towards a management model for Cameroon's dense forests. Biodiversity and Conservation, 18(10): 2705-2718.

VEUTHEY, S., and GERBER, J. F. 2009. Logging conflicts in Southern Cameroon: A feminist ecological economics perspective. Ecological Economics.

VIDAL, N. G. 2004. Forest company-community agreements in Brazil: Current status and opportunities for action: Forest Trends, Washington D.C., USA, 61 p.

WORLD BANK. 2009. Rethinking forest partnerships and benefit sharing: Insights on factors and context that make collaborative arrangements work for communities and landowners. The World Bank Agriculture and Rural Development Department, Washington D.C., U.S.A.

YASMI, Y., ANSHARI, G. Z., ALQADRIE, S., BUDIARTO, T., NGUSMANTO, ABIDIN, E., AFIFUDIN. 2005. The complexities of managing forest resources in postdecentralization Indonesia: a case study from Sintang District, West Kalimantan. CIFOR, Bogor, Indonesia.

\section{APPENDIX}

Table 1 discusses studies that were used in this literature review, which perform moderately to well on the two review criteria of (1) reliability, precision and uncertainty, and (2) validity. The table summarizes each study's performance on these criteria, and presents some additional notes that are relevant to this paper.

TABLE 1 Qualitative Assessment of Empirical Studies

\begin{tabular}{llll}
\hline Source & $\begin{array}{l}\text { Reliability, precision, } \\
\text { and uncertainty } \\
\text { assessment }\end{array}$ & Validity assessment & Notes \\
\hline Andersson 2003 & $\begin{array}{l}\text { High - the random } \\
\text { sample is representative } \\
\text { of the population of the } \\
\text { Bolivian Lowlands }\end{array}$ & $\begin{array}{l}\text { High, as the measures of incentives } \\
\text { are indirect quite direct/ }\end{array}$ & $\begin{array}{l}\text { Three institutional factors - central } \\
\text { government funding, central government } \\
\text { monitoring, and pressure from the } \\
\text { electorate - are found to motivate good } \\
\text { forest governance by municipal officials } \\
\text { in Bolivia }\end{array}$ \\
\hline Andersson 2004 & $\begin{array}{l}\text { High - the sample is } \\
\text { representative of the } \\
\text { population of municipali- } \\
\text { ties that provide forestry } \\
\text { services in Lowland } \\
\text { Bolivia. }\end{array}$ & $\begin{array}{l}\text { High, as direct measures of } \\
\text { interactions between local } \\
\text { governments and other forestry } \\
\text { organizations were used. }\end{array}$ & $\begin{array}{l}\text { Frequency of regular interactions - both } \\
\text { horizontal and vertical - are powerful } \\
\text { predictors of local governance performance } \\
\text { in the forestry sector. }\end{array}$ \\
\hline $\begin{array}{l}\text { High - the sample is } \\
\text { known to be representa- } \\
\text { tive of the population of } \\
\text { municipalities that } \\
\text { provide forestry services } \\
\text { in Lowland Bolivia. }\end{array}$ & $\begin{array}{l}\text { High, as direct measures of } \\
\text { interactions between local } \\
\text { governments and other forestry } \\
\text { organizations were used. }\end{array}$ & $\begin{array}{l}\text { Frequency of regular interactions -- both } \\
\text { horizontal and vertical -- are powerful } \\
\text { predictors of local governance performance } \\
\text { in the forestry sector. }\end{array}$ \\
\hline
\end{tabular}


TABLE 1 Continued

\begin{tabular}{|c|c|c|c|}
\hline Source & $\begin{array}{l}\text { Reliability, precision, } \\
\text { and uncertainty } \\
\text { assessment }\end{array}$ & Validity assessment & Notes \\
\hline
\end{tabular}

\begin{tabular}{ll}
\hline Andersson et al. & Random sample of local \\
2006 & governments in Bolivia \\
& $(\mathrm{n}=100)$ and in Guate- \\
& mala $(\mathrm{n}=100)$. Sampling \\
& error $<5$ percent. High \\
& reliability
\end{tabular}

Andersson and van Random sample of local Laerhoven 2007 governments in Brazil, Chile, Peru and Mexico $(n=390)$, moderate to high reliability.

$\begin{array}{ll}\text { Becker and } & \text { Sampling procedure not } \\ \text { Ghimire 2003 } & \text { reported, so this criterion } \\ & \text { is difficult to assess. }\end{array}$

$\begin{array}{ll}\text { Boscolo et al. } & \text { High. The concession } \\ 2010 & \text { sample was stratified to } \\ & \text { be geographically } \\ & \text { representative. }\end{array}$

Cerutti et al. 2010 Reliability unknown; sampling procedure for eight sampled councils is not given.

High, as the measures of incentives are quite direct.

Moderately high, as indirect measures of incentives for co-provision and co-production of services.

Moderate-high, as areas with NGOs and without had households report conservation attitudes and ecological knowledge, and connections between issues were discussed clearly.

High, as the measures of concepts (whether sustainable forest management plans were adopted) were direct.

High, as measures have face validity (e.g., magnitude of area fees, sources of political decision making).

High, as measures of relevant

de Jong et al. 2006 Difficult to assess because degree to which cases are representative is not discussed.

concepts are used (outcomes, area requested, area ceded).

High, as data on NTFP was collected rigorously. Questions about livelihoods linked to NTFP possess face validity.

Convenience sample wa used, so reliability and precision are not known

$\begin{array}{ll}\text { Donovan and Puri } & \text { Convenience sample was } \\ \text { used, so reliability and } \\ \text { precision are not known }\end{array}$

Ellis and Porter-Bolland

High, as data was collected through remote sensing

High to moderate, as distances, populations, roads and land cover change were measured very directly.

Ezzine de Blas et al. 2011
High, as villages were stratified to include appropriate biomes
High, as typology of conflicts accounts for known characteristics. The approach yields high internal validity.
Three institutional factors - central government funding, central government monitoring, and pressure from the electorate - are found to motivate good forest governance by municipal officials in Bolivia

Pressure from below seems to be the driving force for explaining investments in participatory governance.

Filed surveys and observations were used to determine the impact of information sharing on conservation in Western Ecuador

Factors such as proximity to markets, tenure of forest managers, and technical assistance from the government all predisposed the adoption of sustainable practices in Bolivia

Mayors are blamed for poor distributions of area fees in villages in Cameroon, but the authors contend that they are scapegoats in a political system that does not have sufficient accountability.

Property rights, institutions, and state involvement are found to play key roles in determining the outcomes of conflicts over forest land between communities and companies.

Local people in Borneo were asked to provide information on harvesting non-timber forest products, and the extent and type of traditional ecological knowledge \& expertise was compiled

Landsat data used, in conjunction with institutional and socioeconomic data (distance to roads/markets), to determine likelihood of deforestation Mexican regions.

20 villages in Cameroon sampled to study conflict. Rent distributions and leadership issues seem to drive conflicts in the region. 
TABLE 1 Continued

\begin{tabular}{llll}
\hline Source & $\begin{array}{l}\text { Reliability, precision, } \\
\text { and uncertainty } \\
\text { assessment }\end{array}$ & Validity assessment & Notes \\
\hline
\end{tabular}

\begin{tabular}{llll}
\hline $\begin{array}{l}\text { Gibson and } \\
\text { Lehoucq 2003 }\end{array}$ & $\begin{array}{l}\text { High, as mayors are } \\
\text { randomly sampled }\end{array}$ & $\begin{array}{l}\text { High, as mayors are surveyed } \\
\text { directly about their incentives }\end{array}$ & $\begin{array}{l}\text { Central government support and electoral } \\
\text { pressure lead mayors in Guatemala to value } \\
\text { forest conservation. }\end{array}$
\end{tabular}

Iskander et al. High, as concession plots Moderate, as forests that were

2006 were randomly selected compared (HPH and IPPK) may have had a priori differences

Kellert et al. $2000 \quad$ High, as multiple areas with high sample sizes were used
Moderate, as knowledge, attitudes, and outcomes were all directly assessed; success measured based on these metrics uniformly.
HPH and IPPK concessions in Indonesia yield very different rates of deforestation.

No original data, but rather an analysis of six case studies of cooperative/participatory management strategies in a variety of countries, concluding that institutional, ecological and organizational factors are critical in determining outcomes

Kusters et al. 2007 Very high reliability; random sample of villagers taken with a large $n$, and some data was triangulated via remote sensing.

Lacerda et al. 2010 High, with a comprehensive assessment of tree species in the Brazilian The data has high internal validity, due to multiple measures being employed for many concepts.

Land-use decisions are found to depend on perceptions of tenure security moreso than de jure property rights in the Krui forest of Sumatra, Indonesia.

High, as measures of the value of TEK were well developed and direct

Local expertise is less error-prone in tree identification than reliance on western science alone.

forest of interest was conducted
Larson et al. 2008 Difficult to assess, as within-site sampling procedures were not given.

High internal validity (many concepts in many regions are appropriately measured). Moreover, this study has relatively high external validity because of the high geographic variability among cases

Marfo et al. $2010 \quad$ High, as data was collected in Ghana using purposive samples, and a census in one case.
Moderate, as the links between measures and concepts were direct, although assumptions were discussed in detail
Property rights are shown to be critical in determining outcomes in forests for communities. The study compares cases from several Latin American countries.

Collected data from farmers in Ghana on the circumstances of their interactions w/ concession managers. Modeled the conflicts between the two actors, with strategies such as mediation, litigation, bargaining, arbitration, coalitions, and others

Cooperative arrangements, including outgrowing, concession leasing, corporate social responsibility projects, joint ventures, and community contracts, are examined in a variety of countries. A number of mutual benefits are found to occur in various contexts. Clear property rights are found to be key to making systems work.

\footnotetext{
McCarthy 2001
}

High, as available data from government directly reveals concepts of interest.
Decentralization has empowered local elites in Kalimantan, but the effects on the poor are less clearly positive. Deforestation has continued in spite of decentralization in the region. 
TABLE 1 Continued

\begin{tabular}{llll}
\hline Source & $\begin{array}{l}\text { Reliability, precision, } \\
\text { and uncertainty } \\
\text { assessment }\end{array}$ & Validity assessment & Notes \\
\hline
\end{tabular}

Medina et al. 2009 Difficult to assess, as only High internal validity (many one community with each concepts in many regions are arrangement-type was selected in each region. ascertained with multiple measures), and the geographic diversity lends external validity as well.

Mendoza and

Prabhu 2000

High reliability (representative sample of experts)

Menton et al. 2009 Moderate reliability. The primary field data collection instrument was workshops, which may have attracted a nonrepresentative sample of the population.

Merry et al. 2006 High reliability (random sample of households in the villages of interest)

$\begin{array}{ll}\text { Murti and Boydell } & \begin{array}{l}\text { Reliability unknown, as } \\ \text { the representativeness of } \\ \text { cases is not discussed }\end{array}\end{array}$

Ndoye et al. 2003 High reliability (random sample of traders in the area of study)

Nebel et al. 2003

Unknown, as data collection procedures are not disclosed. Data is from an "efficient, anonymous concession."

Nawir et al. 2003 Moderate, with some selection bias (companies voluntarily participated)
Measures of concepts such as participation in associations, and perceptions of the quality of the associations are direct and the study has high validity.

High, given the authors conclusions; the assessment of case studies shows that conflict prevention would be a good thing.

\section{High, as economic values of NTFPs} were measured by surveys, and the degree to which they accrue to traders was measured directly in

High, as concepts such as price are directly measurable this fashion.
The benefits accrued to households from several forestry schemes are studied in Latin America.

CIFOR C\&I were field tested under a multiple criteria decision making model, with a team of experts in Kalimantan. Team included ecologist, forest scientist, social scientist and administrator

Community-company partnerships were found to be beneficial to households in Brazil, bringing in income without compromising NTFP harvests.
In the Brazilian Amazon, participation in community associations is correlated with better logging contracts and higher satisfaction with these instruments of collective action.

Conflicts in Fiji are shown to prevent the benefits of forests from being realized.

NTFPs are found to have high value to communities in the Congo Basin, and timber markets fail to capture these values.

Opportunities for income for communities are explored up and down the timber production and processing chain.
High, as reasons for and impacts of Three case studies were conducted, in collaboration are directly addressed. There are, notably, no control groups. sion holders, wherein local inhabitants association with the three private conceswere surveyed for a variety of indicators (utilization of land, reasons for entering into cooperative arrangements, and others)

No original data; assessment of existing data on Bolivian forest policy and outcomes

Case study of East Kalimantan, villagers were consulted to determine the impact of decentralization and the types of conflict resolution mechanisms available 
TABLE 1 Continued

\begin{tabular}{|c|c|c|c|}
\hline Source & $\begin{array}{l}\text { Reliability, precision, } \\
\text { and uncertainty } \\
\text { assessment }\end{array}$ & Validity assessment & Notes \\
\hline
\end{tabular}

Purnomo et al. High - Simulations (2003) provide uncertainty specification in collaboration models, with relatively tight distributions

Ros-tonen et al. Reliability may be low 2008 because only one or two cases were investigated for each type of community-company partnership

Qualitatively, assumptions of model appear robust; real world triangulation would be necessary for further assessment of validity

Original data wasn't collected, but existing knowledge was used to model outcomes of varying degrees of community/concessionholder cooperation

High internal validity. Social benefits measured via households, concepts like equity measured by examining differences between genders.

Politically oriented partnerships between communities, NGOs and other groups (companies?) are advocated in light of their observed benefits. A case study of a movement opposed to the construction of a dam in Brazil is highlighted in this context.

Variables like size and nationalization of concessions affect the pressure exerted on forests and the benefits accrued from forests in the Congo Basin. including species harvested were measured through surveys)

High, with robust longitudinal approach to assessing the use of knowledge not discussed

Somerville et al. Moderate, with a $2010 \quad$ convenience sample employed, though with a reasonable samples size.
High, with direct measures through interviews.
They find that technical and ecological knowledge lead to effective forest management by people in the Brazilian Amazon.
They survey community members in areas under the Durrell management scheme - a payment for ecological services, wherein communities manage wildlife, prevent illegal logging, and ensure that new agriculture is not started. They find that some community members benefit, while others do not.

Thapa et al. 1995 High, with random sample in Solma Village, uncertainty specification is possible.
External validity unknown (do farmers in other places possess similar knowledge?), but the concept (knowledge) is linked tightly to the measures - requests about specific information.

\section{High internal validity given the} appropriate measures of benefit distributions with triangulation from multiple measures.
Ecological knowledge of farmers in agroforestry systems was compiled through questionnaires \& ecological inventories
Tokede et al. 2005 High, with participatory research conducted in Papua to gauge impacts of community concessions, with households and elites sampled.

Turner et al. 2000 Difficult to assess, as convenience sample was used
Moderate, as TEK was inventoried comprehensively.
They find that while benefits may accrue to communities in Papua where there are community concessions, there is a high risk of elites capturing benefits; the benefits do not appear to be equitably distributed in many cases.

While no formal survey or interview was administered in the study of traditional ecological knowledge in British Columbia, ethnographic data was collected through conversations with key informants. 
TABLE 1 Continued

\begin{tabular}{|c|c|c|c|}
\hline Source & $\begin{array}{l}\text { Reliability, precision, } \\
\text { and uncertainty } \\
\text { assessment }\end{array}$ & Validity assessment & Notes \\
\hline $\begin{array}{l}\text { Van Vliet et al. } \\
2008\end{array}$ & $\begin{array}{l}\text { High, with wildlife } \\
\text { collected through a robust } \\
\text { transect methodology. }\end{array}$ & $\begin{array}{l}\text { High with direct measures of } \\
\text { concepts }\end{array}$ & $\begin{array}{l}\text { They find that some wildlife avoid roads, } \\
\text { and others do not; they propose that } \\
\text { accounting for these distribution patterns } \\
\text { may help reduce the impacts of logging on } \\
\text { biodiversity }\end{array}$ \\
\hline $\begin{array}{l}\text { Vermeulen et al. } \\
2009\end{array}$ & $\begin{array}{l}\text { High, with robust } \\
\text { sampling procedure }\end{array}$ & $\begin{array}{l}\text { High, as hunting outcomes are } \\
\text { measured directly }\end{array}$ & $\begin{array}{l}\text { They looked at hunting sharing in conces- } \\
\text { sion areas, and find that it doesn't reduce } \\
\text { logging necessarily, and it is unclear that } \\
\text { there are benefits to having communities } \\
\text { hunt. }\end{array}$ \\
\hline Vidal 2003 & $\begin{array}{l}\text { High, as companies in } \\
\text { Brazil were grouped } \\
\text { according to characteris- } \\
\text { tics, and random samples } \\
\text { in each group were } \\
\text { studied. }\end{array}$ & $\begin{array}{l}\text { High, as study directly assesses } \\
\text { characteristics companies valued in } \\
\text { partnerships with communities }\end{array}$ & $\begin{array}{l}\text { Out-grower schemes dare examined in } \\
\text { Brazil. }\end{array}$ \\
\hline World Bank (2010) & $\begin{array}{l}\text { Moderate, with selection- } \\
\text { bias present, so alterna- } \\
\text { tive samples may produce } \\
\text { different results. }\end{array}$ & $\begin{array}{l}\text { Moderate (Questions about "what's } \\
\text { important" not triangulated with } \\
\text { multiple measures/methods) }\end{array}$ & $\begin{array}{l}\text { Survey/Interview on what's important in } \\
\text { cooperative agreements; companies and } \\
\text { NGO experts primarily }\end{array}$ \\
\hline Yasmi et al. 2005 & $\begin{array}{l}\text { Moderate, as convenience } \\
\text { sample was utilized. }\end{array}$ & $\begin{array}{l}\text { High, with participatory and rapid } \\
\text { rural appraisals were used to } \\
\text { develop measures of concepts. }\end{array}$ & $\begin{array}{l}\text { They find that decentralization has not } \\
\text { proceeded in a uniform fashion. In spite of } \\
\text { communities being "empowered," common } \\
\text { people do not actually participate in the } \\
\text { governance of forests. Local elites and } \\
\text { governments dominate decision making by } \\
\text { far. }\end{array}$ \\
\hline
\end{tabular}

